\title{
Analisis Persepsi Mahasiswa dan Dosen Akuntansi Fakultas Ekonomi Universitas Lancang Kuning terhadap Pemberlakuan Masyarakat Ekonomi Asean (MEA)
}

\author{
DINI ONASIS \\ Universitas Lancang Kuning \\ Jln. Yos Sudarso KM 08 Rumbai Pekanbaru \\ E-mail : onasisdini@gmail.com
}

\begin{abstract}
Perception needs to be investigated because it is an understanding of MEA implementation. With some knowledge, understanding and willingness, it is expected that the MEA implementation is not new and generate a lot of negative sentiments from accountants and accounting students in Indonesia. The scope of the research is on the perception of Accounting students at the Faculty of Economics, University of Lancang Kuning, and perception of Accounting Lecturer Faculty of Economics, University of Lancang Kuning towards the application of MEA in the field of accounting profession. Perception needs to be examined to be able to map the portrait of understanding and readiness of Students in facing the MEA, and the achievement of Teaching Material from Accounting Lecturers Faculty of Economics, University of Lancang Kuning. The type of research conducted is quantitative research to determine the casual relationship (cause-effect) between independent variables and dependent variable that serves to estimate and control the symptoms. This study examines the perceptions of Accounting Lecturers and accounting students towards the implementation of MEA in the field of accounting profession. Perceptions gained from Accounting Lecturers and accounting students will be collected and processed, so that the formulation of the hypothesis can be answered. There is no difference of perception between Lecturer of Accounting and Accounting Student for: MEA's General View in Accounting Profession Field, MEA Implication in Accounting Profession Field, MEA Competition in Accounting Profession Field, and Professional Accountant Requirement. But besides showing the perception of Accounting Lecturers better than Accounting Students, but also found the perception of accounting students about MEA's general views and MEA implications in the field of accounting profession is better than the Lecturer of Accounting. In the perception of MEA Competition in Accounting Profession Division found better perception of accounting student compared with Accounting Lecturer. So vice versa on perceptions Professional Accounting Needs Lecturer Accounting perception is better than accounting students.
\end{abstract}

Keywords: MEA, Accounting Lecturers, accounting students

Adanya MEA membawa kesempatan besar bagi semua tenaga kerja warga negara ASEAN dan tentunya membawa sejumlah peluang dan tantangan. Sebagai contoh, seseorang yang berwarga Negara Indonesia dapat bekerja di Singapura, Thailand, Malaysia, Filipina, Vietnam dan lain-lain. Secara kuantitatif, Indonesia memiliki keunggulan dibandingkan beberapa negara lain, sehingga dapat memaksimalkan kesempatan ini. Namun di sisi lain, Indonesia akan dihadapkan dengan berbagi ancaman apabila Sumber Daya Manusia (SDM) belum siap. Artinya peluang kerja akan diambil oleh tenaga kerja asing dan
Indonesia akan menjadi penonton di negeri sendiri.

Dalam blue print MEA, terdapat empat prioritas dalam kerangka MEA, (Suatma, 2012) yaitu:

1. Adanya arus barang dan jasa yang bebas (free flow food and services)

2. Ekonomi regional yang kompetitif (competitive economic region)

3. Perkembangan ekuitas ekonomi (equitable economic development)

4. Integrasi memasuki ekonomi global (full integration into global economy).

Mahasiswa akuntansi pada hakikatnya merupakan calon akuntan 
yang akan menjadi akuntan publik dan non publik. Hal ini berarti bahwa mahasiswa akuntansi harus menyadari segala perkembangan yang ada di dalam ruang lingkup profesionalisme dunia akuntan. Apalagi dengan adanya MEA, sehingga dibutuhkan effort yang lebih untuk dapat mempersiapkan diri secara maksimal dan akan siap bersaing dengan beberapa tenaga kerja asing.

Pekanbaru merupakan ibu kota Provinsi Riau yang berada di wilayah pulau sumatera. Pekanbaru bukan kota industri atau bukan pusat bisnis seperti Jakarta dan pulau jawa, yang lebih cepat menerima segala informasi dibanding penduduk kotakota di daerah. Sementara Prodi Akuntansi Fakultas Ekonomi (FE) Universitas Lancang Kuning (UNILAK) memiliki mahasiswa yang sebagian besar berasal dari penduduk daerah di luar ibukota yang berada di daerah-daerah yang merupakan daerah kecil yang pengelolaannya daerahnya dikelola oleh seorang bupati.

Prodi Akuntansi FE UNILAK memiliki mahasiswa-mahasiswa yang berasal dari beragam demografi yang tentu memiliki pemahaman yang berbeda satu sama lainnya mengenai MEA, apalagi keterbatasan daerah akan mempengaruhi pemahaman mahasiswa akan MEA.

Untuk mengukur pemahaman mahasiswa mengenai pemberlakuan MEA dalam bidang akuntansi, maka persepsi perlu diteliti atas pemahaman terhadap pemberlakuan MEA. Dengan sejumlah pengetahuan, pemahaman dan kemauan maka diharapkan pemberlakuan MEA bukanlah hal baru dan menimbulkan banyak sentimen negatif dari akuntan dan mahasiswa akuntansi di Indonesia.

Ruang lingkup penelitian adalah pada Persepsi mahasiswa Akuntansi pada Fakultas Ekonomi Universitas Lancang Kuning, dan persepsi Dosen Akuntansi Fakultas Ekonomi Universitas Lancang Kuning terhadap pemberlakuan MEA di bidang profesi akuntan.



Mahasiswa Akuntansi UNDIP, UNIKA, UNNES, UNISSULA, UDINUS, UNISBANK, STIE TOTAL Win dan Mahasiswa PPA UNDIP) mengemukakan bahwa berdasarkan faktor gaji, responden lebih memilih menjadi akuntan perusahaan. Faktor pelatihan profesional dan pengakuan profesional, responden memilih akuntan publik. Berdasarkan nilai-nilai sosial, lingkungan kerja, dan kesetaraan gender, responden memilih menjadi akuntan pendidik. Hal menarik dari penelitian ini ialah tidak ditemukan perbedaan persepsi antara mahasiswa dan mahasiswi akuntansi, mengenai profesi akuntan baik akuntan publik, akuntan, akuntan pendidik, akuntan perusahaan dan akuntan pemerintah.

Penelitian Andadari (2013) yang menguji persepsi mahasiswa terhadap pemberlakuan ASEAN ECONOMIC COMMUNITY yang hasilnya 113 mahasiswa Indonesia yang belum mengetahui apa itu ASEAN Economic Community 2015 dan 47,8 \% mahasiswa Indonesia menguasi teknologi informasi serta 52,2 lulusan tidak siap menghadapi ASEAN Economic Community 2015 dan 16,8 siap menghadapi tantangan ASEAN Economic Community 2015.

Suttipun (2014) hasil penelitian menyatakan dari analisis regresi menunjukan bahwa "Hubungan kompetensi pengetahauan, kemampuan, dan etika berpengaruh positif dan signifikan terhadap mahasiswa akuntansi di Thailand dalam menghadapi ASEAN Economic Community 2015".

Persepsi perlu di kaji untuk dapat memetakan potret pemahaman dan kesiapan Mahasiswa dalam menghadapi MEA, dan pencapaian Materi Pengajaran dari Dosen-dosen Akuntansi Fakultas Ekonomi Universitas Lancang Kuning.

Berdasarkan latar belakang diatas maka kami Tim Penelitian Fakultas Ekonomi Universitas Lancang Kuning melakukan Penelitian dengan Judul "Analisis Persepsi Mahasiswa dan Dosen Akuntansi Fakultas Ekonomi Universitas 
Lancang Kuning terhadap Pemberlakuan Masyarakat Ekonomi Asean (MEA)",

Berdasarkan latar belakang penelitian, dapat dirumuskan masalahmasalah sebagai berikut:

1. Apakah terdapat perbedaan persepsi yang signifikan antara mahasiswa akuntansi dan Dosen Akuntansi mengenai pandangan umum MEA di bidang Profesi akuntan ?

2. Apakah terdapat perbedaan persepsi yang signifikan antara mahasiswa akuntansi dan Dosen Akuntansi mengenai implikasi MEA di bidang Profesi akuntan?

3. Apakah terdapat perbedaan persepsi yang signifikan antara mahasiswa akuntansi dan Dosen Akuntansi mengenai persaingan MEA di bidang Profesi akuntan?

4. Apakah terdapat perbedaan persepsi yang signifikan antara mahasiswa akuntansi dan Dosen Akuntansi mengenai kebutuhan akuntan?

Profesi akuntan adalah semua bidang pekerjaan yang mempergunakan keahlian di bidang akuntansi, termasuk bidang pekerjaan akuntan publik, akuntan internal yang bekerja pada perusahaan industri,keuangan atau dagang, akuntan yang bekerja dipemerintah, dan akuntan pendidik (Triani dkk., 2015).

Persepsi merupakan pandangan atau perspektif seseorang mengenai suatu hal, serta dapat memutuskan stimulus dalam suatu gambaran apa yang sesuai dengan pandangan atau perspektif tersebut (Kotler, 1993).

Winarna (2004) menjelaskan yang dapat menimbulkan persepsi sedikitnya memuat beberapa unsur-unsur sebagai berikut:

a. Adanya obyek yang dipersepsikan (physical).

b. Alat indera untuk menerima stimulus (fisiologis).

c. Adanya perhatian (attention) yang merupakan langkah pertama (first step) dalam mengadakan persepsi (psikologis).
Oleh sebab itu untuk mengembangkan persepsi harus memiliki unsur obyek, alat indera dan perhatian dari individu mengenai suatu hal yang ditimbulkan dari reaksi lingkungan sekitar yang membuat individu tersebut dapat memutuskan mengenai suatu hal.

MEA merupakan suatu kesepakatan negara-negara ASEAN dalam rangka mewujudkan visi ASEAN 2020 yang telah disusun sejak tahun 1997 di Kualalumpur. Dalam mewujudkan visi ASEAN 2020, terdapat 3 pilar komunitas ASEAN yang mana salah satunya adalah ASEAN Economic Community (AEC) yang berfokus pada menjadikan negaranegara ASEAN sebagai kawasan perdagangan bebas barang, jasa, investasi, tenaga kerja, dan aliran modal.

MEA ataupun AEC memberikan kawasan perdagangan bebas bagi negara-negara ASEAN, serta menciptakan pasar regional bagi penduduk ASEAN (Avianti, 2015).

Ilmu Akuntansi dan pengetahun mengenai MEA didapat oleh Mahasiswa Akuntansi dan Dosen Akuntansi di lingkungan akademik dan diluar lingkungan akademik, mengarahkan kepada kesiapan kematangan Profesionalisme Mahasiswa dan Dosen Akuntansi secara tidak langsung. Suyatmin (2008) menilai bahwa kesiapan yang menyangkut profesionalisme memuat keahlian (skill), karakter (character), dan pengetahuan (knowledge).

Sulistyawati (2013) menjelaskan terdapat Nilai-nilai personalitas dan sosial tidak memiliki perbedaan yang signifikan pada persepsi mahasiswa akuntansi mengenai pemilihan karir. Lebih lanjut dalam penelitian tersebut diungkapkan bahwa personalitas merupakan permasalahan penting yang dihadapi individu saat berhadapan dengan kondisi tertentu. Hal ini berarti bahwa personalitas berpengaruh terhadap perilaku seseorang. Dalam penelitian tersebut responden penelitian 
menganggap tidak adanya perbedaan bagi mahasiswa akuntansi untuk memilih karir menjadi akuntan.

Lebih lanjut Rahayu (2003) menilai bahwa mahasiswa akuntasi yang berkualitas mampu menjawab perkembangan dunia bisnis. Oleh karena itu, diperlukan suatu stimulasi agar mahasiswa akuntansi secara serius mempersiapkan karir dengan memanfaatkan fasilitas kampus secara optimal.

\section{Gambar 1 Kerangka Pemikiran}

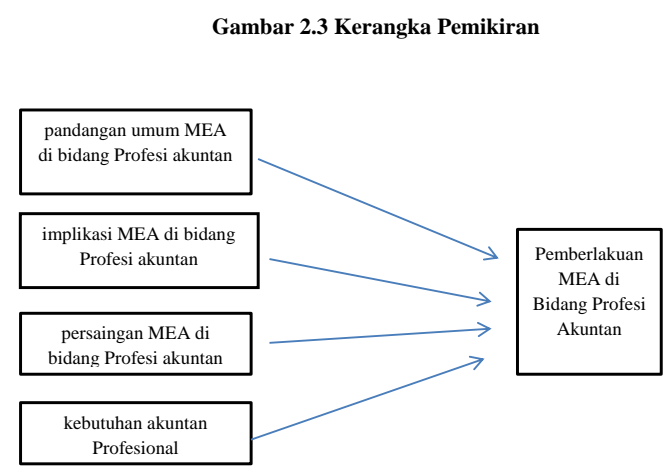

\section{METODE}

Jenis penelitian yang dilakukan ialah penelitian kuantitatif untuk mengetahui hubungan kasual (sebab-akibat) antara variabel independen dan variabel dependen yang berfungsi untuk mengestimasi dan mengendalikan gejala. Penelitian ini menguji persepsi Dosen Akuntansi dan mahasiswa akuntansi terhadap pemberlakuan MEA di bidang profesi akuntan. Persepsi yang diperoleh dari Dosen Akuntansi dan mahasiswa akuntansi akan dikumpulkan dan diolah, sehingga perumusan hipotesis dapat terjawab.

Penelitian ini menguji hipotesis yang dikembangkan, agar identifikasi berbagai variabel jelas dan konsisten mulai dari definisi, ukuran dan skala. Identifikasi dan definisi pengukuran veriabel-variabel tersebut adalah sebagai berikut:

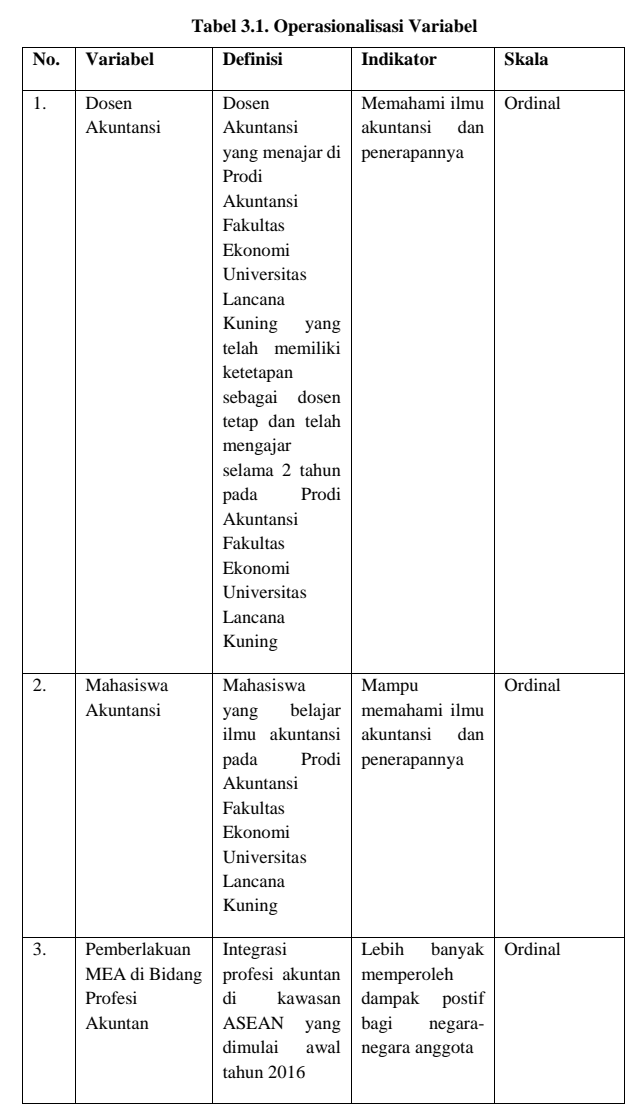

Populasi yang digunakan dalam penelitian ini adalah 16 orang Dosen Tetap Akuntansi di Prodi Akuntansi Fakultas Ekonomi Universtias Lancang Kuning, serta 16 mahasiswa akuntansi angkatan 2014. Tahun 2018 dipilih menjadi periode penilitian karena ingin memperoleh data yang terbaru mengenai pemberlakuan MEA di bidang profesi akuntan yang sedang berlangsung.

Teknik pengambilan sampel yang digunakan dalam penelitian ini adalah purposive accidental sampling untuk Mahasiswa Akuntansi dengan kriteria mahasiswa akuntansi yang telah mempelajari mata kuliah Akuntansi Keuangan Menengah 2 serta mata kuliah Teori Akuntansi.

Jenis data yang digunakan dalam penelitian ini adalah opinion data dengan mengolah data primer dengan penyebaran kuesioner kepada Dosen dan Mahasiswa Akuntansi. Data opini tersebut diperoleh melalui kuesioner (personally administtred quistionries), yang didistribusikan kepada 
setiap responde, Setelah itu, data-data tersebut dikumpulkan dan diolah untuk memperoleh hasil yang berkenaan dengan penelitian.

Teknik pengumpulan data dalam tulisan ini ialah survey dengan menyebarkan kusioner ke beberapa Mahasiswa dan Dosen Akauntansi pada Prodi Akuntansi Fakultas Ekonomi Universitas Lancang Kuning. Pengumpulan data juga dilengkapi dengan studi kepustakaan dengan mempelajari beberapa literatur, buku dan jurnal yang berkaitan dengan tulisan ini.

\section{HASIL}

Hasil Pengujian Validitas

Hasil pengujian lengkap dapat ditelusuri di table berikut :

\begin{tabular}{|c|c|c|c|c|}
\hline \multicolumn{5}{|c|}{ Item-Total Statistics } \\
\hline & $\begin{array}{l}\text { Scale Mean if } \\
\text { Item Deleted }\end{array}$ & $\begin{array}{l}\text { Scale Variance } \\
\text { if Item Deleted }\end{array}$ & $\begin{array}{c}\text { Corrected Item- } \\
\text { Total } \\
\text { Correlation }\end{array}$ & $\begin{array}{c}\text { Cronbach's } \\
\text { Alpha if Item } \\
\text { Deleted }\end{array}$ \\
\hline UMUM1 & 45.6563 & 36.943 & .543 & .771 \\
\hline UMUM2 & 46.3750 & 38.113 & .222 & .801 \\
\hline UMUM3 & 45.6563 & 37.459 & .360 & .785 \\
\hline UMUM4 & 45.7813 & 34.822 & .522 & .769 \\
\hline IMP1 & 46.7188 & 38.725 & .222 & .798 \\
\hline IMP2 & 45.5625 & 38.577 & .305 & .789 \\
\hline IMP3 & 45.3438 & 37.330 & .484 & .775 \\
\hline PERS1 & 46.3125 & 36.415 & .516 & .771 \\
\hline PERS2 & 46.5938 & 35.797 & .453 & .776 \\
\hline PERS3 & 46.4688 & 35.160 & .462 & .775 \\
\hline KEB1 & 45.2813 & 37.564 & .449 & .777 \\
\hline KEB2 & 45.1250 & 36.435 & .532 & .770 \\
\hline KEB3 & 45.0000 & 36.194 & .570 & .767 \\
\hline
\end{tabular}

Berdasarkan tabel di atas, hasil Corrected Item-Total Correlation memiliki angka diatas 0,2 dan tidak ada yang dibawah 0,2. Maka hasil pengujian validitas menunjukan bahwa semua pernyataan dalam setiap variabel valid dan mampu mengungkapkan persepsi Dosen Akuntansi dan mahasiswa akuntansi terhadap permberlakuan MEA di bidang profesi akuntan.

\section{Hasil Pengujian Reliabilitas}

Berikut hasil pengujian reliabilitas :

\section{Reliability Statistics}

Cronbach's Alpha N of Items

$\frac{13}{.793}$
pernyataan reliabel dengan nilai alpha 0,793 .

Hasil Pengujian Normalitas

Hasil pengujian ditunjukan dalam tabel berikut:

One-Sample Kolmogorov-Smirnov Test

\begin{tabular}{llr} 
& & TOTAL \\
\hline $\mathrm{N}$ & & 32 \\
\hline Normal Parameters & Mean & 49.6563 \\
\cline { 2 - 3 } & Std. Deviation & 6.52345 \\
\hline Most Extreme Differences & Absolute & .179 \\
\cline { 2 - 3 } & Positive & .081 \\
\cline { 2 - 3 } & Negative & -.179 \\
\hline Test Statistic & .179 \\
\hline Asymp. Sig. (2-tailed) & $.011^{\mathrm{c}}$ \\
\hline $\begin{array}{l}\text { a. Test distribution is Normal. } \\
\text { b. Calculated from data. }\end{array}$ \\
$\begin{array}{l}\text { c. Lilliefors Significance Correction. } \\
\end{array}$
\end{tabular}

Hasil pengujian menunjukan bahwa semua nilai signifikansi uji normalitas dengan metode Kolmogorov-Smirnov (K-S). Hal ini berarti semua data berdistribusi normal. Hasil Pengujian Hipotesis (Independent Sample T-Test dan Statistik Deskriptif)

Pandangan Umum MEA di Bidang Profesi Akuntan.

Hasil pengujian Independent Sample T-Test variabel pandangan umum MEA di bidang profesi akuntan adalah sebagai berikut :



Setelah kita lihat homogenitas, maka Angka pada Sig. (2-tailed) adalah angka yang menunjukkan signifikansi data. Signifikansi data (Sig. (2-tailed)) menunjukkan lebih besar dari 0.05 yaitu untuk pandang umum 1 adalah 0,650 dan 0,651 , untuk pandangan umum 2 adalah 0,089 dan 0,089 , untuk pandangan umum 3 adalah 0,716 dan 0,717 , untuk pandangan umum 4 adalah 0,330 dan 0,330 , artinya tidak ada perbedaan yang signifikan antara Dosen Akuntansi dan Mahasiswa Akuntansi dalam pandangan 
Umum mengenai MEA di Bidang Profesi Akuntan.

Nilai signifikansi lebih besar dari 0,05 maka hipotesis penelitian (alternatif) ditolak dan hipotesis nol diterima. Hipotesis nol menyebutkan bahwa tidak terdapat perbedaan persepsi antara Dosen Akuntansi dan mahasiswa akuntansi ditinjau dari pandangan umum pemberlakuan MEA di bidang profesi akuntan.

Implikasi MEA di Bidang Profesi Akuntan.

Hasil pengujian Independent Sample T-Test variabel pandangan umum MEA di bidang profesi akuntan adalah sebagai berikut :



Setelah kita lihat homogenitas, maka Angka pada Sig. (2-tailed) adalah angka yang menunjukkan signifikansi data. Signifikansi data (Sig. (2-tailed)) menunjukkan lebih besar dari 0.05 yaitu untuk Implikasi 1 adalah 0,733 dan 0,734, untuk Implikasi 2 adalah 0,151 dan 0,151, untuk Implikasi 3 adalah 0,373 dan 0,376, artinya tidak ada perbedaan yang signifikan antara Dosen Akuntansi dan Mahasiswa Akuntansi dalam Persepsi Implikasi MEA di Bidang Profesi Akuntan.

Nilai signifikansi lebih besar dari 0,05 maka hipotesis penelitian (alternatif) ditolak dan hipotesis nol diterima. Hipotesis nol menyebutkan bahwa tidak terdapat perbedaan persepsi antara Dosen Akuntansi dan mahasiswa akuntansi ditinjau dari Implikasi MEA di Bidang Profesi Akuntan.
Persaingan MEA di Bidang Profesi Akuntan.

Hasil pengujian Independent Sample TTest variabel pandangan umum MEA di bidang profesi akuntan adalah sebagai berikut :

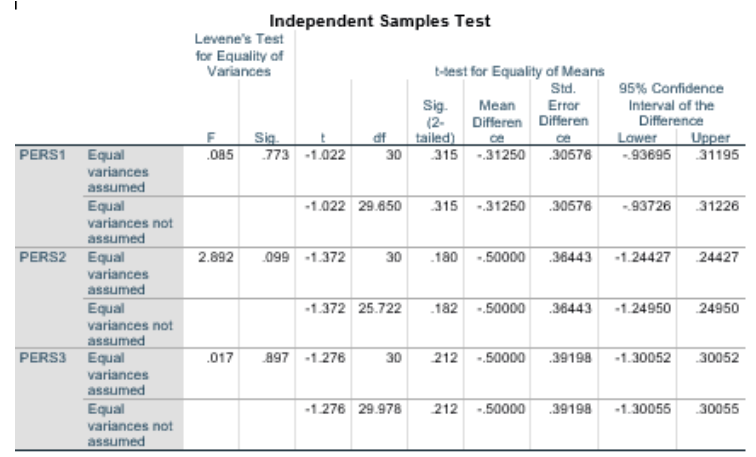

Setelah kita lihat homogenitas, maka Angka pada Sig. (2-tailed) adalah angka yang menunjukkan signifikansi data. Signifikansi data (Sig. (2-tailed)) menunjukkan lebih besar dari 0.05 yaitu untuk Persaingan 1 adalah 0,315 dan 0,315, untuk Persaingan 2 adalah 0,180 dan 0,182, untuk Persaingan 3 adalah 0,212 dan 0,212, artinya tidak ada perbedaan yang signifikan antara Dosen Akuntansi dan Mahasiswa Akuntansi dalam Persepsi Persaingan MEA di Bidang Profesi Akuntan.

Nilai signifikansi lebih besar dari 0,05 maka hipotesis penelitian (alternatif) ditolak dan hipotesis nol diterima. Hipotesis nol menyebutkan bahwa tidak terdapat perbedaan persepsi antara Dosen Akuntansi dan mahasiswa akuntansi ditinjau dari Persaingan MEA di Bidang Profesi Akuntan.

\section{Kebutuhan Akuntan Profesional.}

Hasil pengujian Independent Sample T-Test variabel pandangan umum MEA di bidang profesi akuntan adalah sebagai berikut : 




Setelah kita lihat homogenitas, maka Angka pada Sig. (2-tailed) adalah angka yang menunjukkan signifikansi data. Signifikansi data (Sig. (2-tailed)) menunjukkan lebih besar dari 0.05 yaitu untuk Kebutuhan 1 adalah 0,663 dan 0,664, untuk Kebutuhan 2 adalah 0,301 dan 0,305, untuk Kebutuhan 3 adalah 0,530 dan 0,533 , artinya tidak ada perbedaan yang signifikan antara Dosen Akuntansi dan Mahasiswa Akuntansi dalam Persepsi Kebutuhan Akuntan Profesional.

Nilai signifikansi lebih besar dari 0,05 maka hipotesis penelitian (alternatif) ditolak dan hipotesis nol diterima. Hipotesis nol menyebutkan bahwa tidak terdapat perbedaan persepsi antara Dosen Akuntansi dan mahasiswa akuntansi ditinjau dari Kebutuhan Akuntan Profesional.

\section{Persepsi Dosen Akuntansi dan Mahasiswa Akuntansi}

Pandangan Umum MEA di Bidang Profesi Akuntan

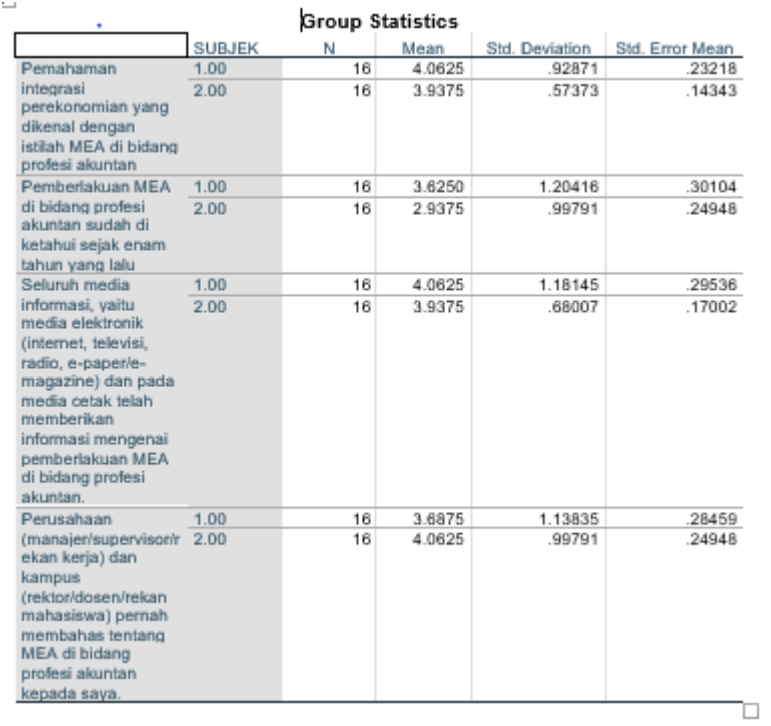

Dari hasil pengujian deskriptif statistik Dosen Akuntansi memiliki nilai mean yang lebih tinggi dibandingkan dengan mahasiswa akuntansi ditinjau dari Pemberlakuan MEA di bidang profesi akuntan sudah di ketahui sejak enam tahun yang lalu. Nilai mean dari Dosen akuntansi 3,6250, sedangkan mahasiswa akuntansi 2,9375, Hal ini menunjukan bahwa persepsi Dosen Akuntansi mengenai pandangan umum MEA di bidang profesi akuntan lebih baik dibandingkan dengan mahasiswa akuntansi.

Dari hasil pengujian deskriptif statistik Dosen Akuntansi memiliki nilai mean yang lebih tinggi dibandingkan dengan mahasiswa akuntansi ditinjau dari Seluruh media informasi melalui media elektronik (internet, televisi, radio, epaper/e-magazine) dan pada media cetak telah memberikan informasi mengenai pemberlakuan MEA di bidang profesi akuntan. Nilai mean dari Dosen akuntansi 4,0625, sedangkan mahasiswa akuntansi 3.9375, Hal ini menunjukan bahwa persepsi Dosen Akuntansi mengenai pandangan umum MEA di bidang profesi akuntan lebih baik dibandingkan dengan mahasiswa akuntansi.

Dari hasil pengujian deskriptif statistik Dosen Akuntansi memiliki nilai mean yang lebih tinggi dibandingkan dengan mahasiswa akuntansi ditinjau dari Perusahaan (manajer/supervisor/rekan kerja) dan kampus (rektor/dosen/rekan mahasiswa) pernah membahas tentang MEA di bidang profesi. Nilai mean dari Dosen akuntansi 3.6875, sedangkan mahasiswa akuntansi 4.0625,. Hal ini menunjukan bahwa persepsi mahasiswa akuntansi mengenai pandangan umum MEA di bidang profesi akuntan lebih baik dibandingkan dengan Dosen Akuntansi. 
Implikasi MEA di Bidang Profesi Akuntan

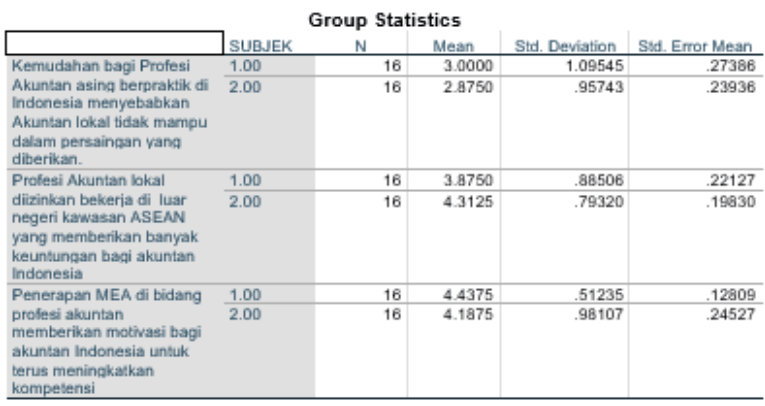

Dari hasil pengujian deskriptif statistik Dosen Akuntansi memiliki nilai mean yang lebih tinggi dibandingkan dengan mahasiswa akuntansi ditinjau dari Kemudahan bagi Profesi Akuntan asing berpraktik di Indonesia menyebabkan Akuntan lokal tidak mampu dalam persaingan yang diberikan. Nilai mean dari Dosen akuntansi 3.0000, sedangkan mahasiswa akuntansi 2.8750. Hal ini menunjukan bahwa persepsi Dosen Akuntansi mengenai Implikasi MEA di Bidang Profesi Akuntan lebih baik dibandingkan dengan mahasiswa akuntansi.

Dari hasil pengujian deskriptif statistik Dosen Akuntansi memiliki nilai mean yang lebih tinggi dibandingkan dengan mahasiswa akuntansi ditinjau dari Profesi Akuntan lokal diizinkan bekerja di luar negeri kawasan ASEAN yang memberikan banyak keuntungan bagi akuntan Indonesia. Nilai mean dari Dosen akuntansi 3.8750, sedangkan mahasiswa akuntansi 4.3125. Hal ini menunjukan bahwa persepsi mahasiswa akuntansi mengenai Implikasi MEA di Bidang Profesi Akuntan lebih baik dibandingkan dengan Dosen Akuntansi.

Dari hasil pengujian deskriptif statistik Dosen Akuntansi memiliki nilai mean yang lebih tinggi dibandingkan dengan mahasiswa akuntansi ditinjau dari Penerapan MEA di bidang profesi akuntan memberikan motivasi bagi akuntan Indonesia untuk terus meningkatkan kompetensi. Nilai mean dari Dosen akuntansi 4.4375, sedangkan mahasiswa akuntansi 4.1875. Hal ini menunjukan bahwa persepsi Dosen Akuntansi mengenai Implikasi MEA di
Bidang Profesi Akuntan lebih baik dibandingkan dengan mahasiswa akuntansi.

\section{Persaingan Mea Di Bidang Profesi Akuntan}

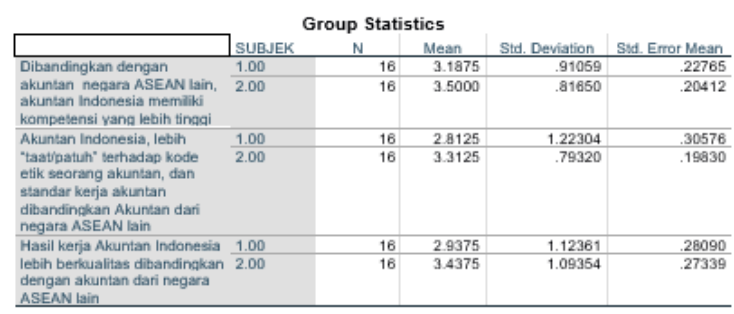

Dari hasil pengujian deskriptif statistik Dosen Akuntansi memiliki nilai mean yang lebih tinggi dibandingkan dengan mahasiswa akuntansi ditinjau dari Perbandingan antara akuntan negara ASEAN lain, dengan akuntan Indonesia memiliki kompetensi yang lebih tinggi. Nilai mean dari Dosen akuntansi 3.1875, sedangkan mahasiswa akuntansi 3.5000 . Hal ini menunjukan bahwa persepsi mahasiswa akuntansi mengenai Persaingan MEA di Bidang Profesi Akuntan lebih baik dibandingkan dengan Dosen Akuntansi.

Dari hasil pengujian deskriptif statistik Dosen Akuntansi memiliki nilai mean yang lebih tinggi dibandingkan dengan mahasiswa akuntansi ditinjau pada Akuntan Indonesia, lebih "taat/patuh" terhadap kode etik seorang akuntan, dan standar kerja akuntan dibandingkan Akuntan dari negara ASEAN lain. Nilai mean dari Dosen akuntansi 2.8125, sedangkan mahasiswa akuntansi 3.3125. Hal ini menunjukan bahwa persepsi mahasiswa akuntansi mengenai Persaingan MEA di Bidang Profesi Akuntan lebih baik dibandingkan dengan Dosen Akuntansi.

Dari hasil pengujian deskriptif statistik Dosen Akuntansi memiliki nilai mean yang lebih tinggi dibandingkan dengan mahasiswa akuntansi ditinjau pada Hasil kerja Akuntan Indonesia lebih berkualitas dibandingkan dengan akuntan dari negara ASEAN lain Nilai mean dari Dosen akuntansi 2.9375, sedangkan mahasiswa akuntansi 3.4375. Hal ini menunjukan bahwa persepsi mahasiswa 
akuntansi mengenai Persaingan MEA di Bidang Profesi Akuntan lebih baik dibandingkan dengan Dosen Akuntansi.

\section{Kebutuhan Akuntan Profesional}

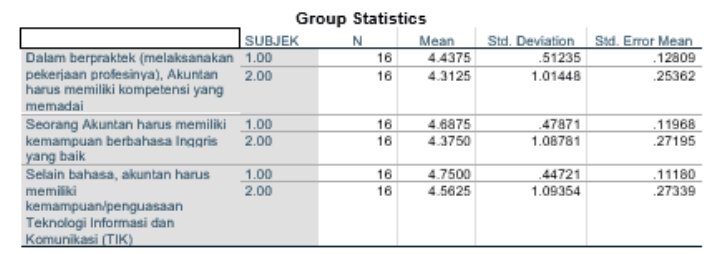

Dari hasil pengujian deskriptif statistik Dosen Akuntansi memiliki nilai mean yang lebih tinggi dibandingkan dengan mahasiswa akuntansi ditinjau Dalam berpraktek (melaksanakan pekerjaan profesinya), Akuntan harus memiliki kompetensi yang memadai. Nilai mean dari Dosen akuntansi 4.4375, sedangkan mahasiswa akuntansi 4.3125. Hal ini menunjukan bahwa persepsi Dosen Akuntansi mengenai Kebutuhan Akuntan Profesional lebih baik dibandingkan dengan mahasiswa akuntansi.

Dari hasil pengujian deskriptif statistik Dosen Akuntansi memiliki nilai mean yang lebih tinggi dibandingkan dengan mahasiswa akuntansi ditinjau pada seorang Akuntan harus memiliki kemampuan berbahasa Inggris yang baik. Nilai mean dari Dosen akuntansi 4.6875, sedangkan mahasiswa akuntansi 4.3750. Hal ini menunjukan bahwa persepsi Dosen Akuntansi mengenai Kebutuhan Akuntan Profesional lebih baik dibandingkan dengan mahasiswa akuntansi.

Dari hasil pengujian deskriptif statistik Dosen Akuntansi memiliki nilai mean yang lebih tinggi dibandingkan dengan mahasiswa akuntansi ditinjau Dalam berpraktek (melaksanakan pekerjaan profesinya), Akuntan harus memiliki kompetensi yang memadai. Nilai mean dari Dosen akuntansi 4.7500, sedangkan mahasiswa akuntansi 4.5625. Hal ini menunjukan bahwa persepsi Dosen Akuntansi mengenai Kebutuhan Akuntan Profesional lebih baik dibandingkan dengan mahasiswa akuntansi.

\section{PEMBAHASAN}

Dosen Akuntansi dan Mahasiswa Akuntansi telah mengetahui dan memahami integrasi perekonomian yang dikenal dengan istilah MEA di bidang profesi akuntan, juga Dosen dan Mahasiswa Akuntansi mengetahui Pemberlakuan MEA di bidang profesi akuntan dimana di ketahui sejak enam tahun yang lalu, informasi adanya Integrasi perekonomian tersebut diperoleh dari beberapa media informasi seperti media elektronik (internet, televisi, radio, e-paper/e-magazine) dan pada media cetak. Namun terdapat persepsi mahasiswa akuntansi lebih baik dibandingkan dengan Dosen Akuntansi mengenai Perusahaan (manajer/supervisor/rekan kerja) dan kampus (rektor/dosen/rekan mahasiswa) pernah membahas tentang MEA di bidang profesi Akuntan.

Namun, secara komprehensif integrasi perekonomian MEA kurang dijelaskan oleh Perusahaan (manajer/supervisor/rekan kerja) dan di lingkungan Akademik /kampus (rektor/dosen/rekan mahasiswa).

Ditinjau dari hasil diatas, maka dari sisi implikasi MEA di bidang profesi akuntan, tidak terdapat perbedaan persepsi antara Dosen Akuntansi dan mahasiswa akuntansi. Hal ini menunjukan bahwa antara Dosen Akuntansi dan mahasiswa akuntansi telah memahami dampak yang ditimbulkan oleh pemberlakuan MEA, seperti kemudahan Profesi Akuntan asing berpraktik di Indonesia menyebabkan Akuntan lokal tidak mampu dalam persaingan yang diberikan, namun mahasiswa memiliki presepsi bahwa Akuntan Lokal diizinkan bekerja di luar negeri kawasan ASEAN yang belum tentu memberikan banyak keuntungan bagi akuntan Indonesia. Namun Pemberlakuan MEA di bidang profesi akuntan tetap memberikan motivasi bagi akuntan Indonesia untuk terus meningkatkan.

Hasil pengujian hipotesis di atas, diperoleh kesimpulan bahwa tidak terdapat perbedaan persepsi Dosen Akuntansi dan mahasiswa akuntansi mengenai persaingan 
di bidang profesi akuntan. Namun hasil pengujian menunjukan bahwa persepsi mahasiswa akuntansi lebih baik dibandingkan dengan persepsi Dosen Akuntansi mengenai persaingan di bidang profesi akuntan. Mahasiswa akuntansi lebih menyadari bahwa Profesi akuntan Indonesia lebih kompeten, lebih taat/patuh terhadap kode etik Profesi akuntan dan standar kerja Akuntan, serta hasil kerja yang lebih berkualitas dibandingkan akuntan asing dari negara ASEAN lainnya. Hal ini dipengaruhi oleh adanya persiapan yang matang dari mahasiswa akuntansi melalui pendidikan yang diperoleh di perguruan tinggi, sehingga segala bentuk persaingan dalam profesi akuntan telah dipelajari sejak awal pada saat memasuki perguruan tinggi. Selain itu, pandangan yang berlaku umum dalam paradigma mahasiswa akuntansi adalah akuntan Indonesia sudah siap untuk menghadapi MEA.

Ditinjau dari segi kebutuhan akuntan profesional, tidak terdapat perbedaan persepsi Dosen Akuntansi dan mahasiswa akuntansi. Hal ini dipengaruhi oleh kesadaran yang tinggi antara Dosen Akuntansi dan mahasiswa akuntansi bahwa untuk menjadi akuntan yang professional, diperlukan kompetensi yang memadai, kemampuan berbahasa Inggris yang baik, dan penguasaan teknologi informasi dan komunikasi (TIK).

\section{SIMPULAN}

Melalui hasil pengujian dan pembahasan diatas maka dapat ditarik suatu kesimpulan bahwa :

Tidak terdapat perbedaan persepsi antara Dosen Akuntansi dan Mahasiswa Akuntansi atas :

1. Pandangan Umum MEA di Bidang Profesi Akuntan

2. Implikasi MEA di Bidang Profesi Akuntan

3. Persaingan MEA di Bidang Profesi Akuntan

4. Kebutuhan Akuntan Profesional

Namun disamping menunjukkan persepsi Dosen Akuntansi lebih baik dari Mahasiswa
Akuntansi, namun ditemukan juga persepsi mahasiswa akuntansi mengenai pandangan umum MEA dan Implikasi MEA di bidang profesi akuntan lebih baik dibandingkan dengan Dosen Akuntansi.

Pada persepsi Persaingan MEA di Bidang Profesi Akuntan ditemukan persepsi mahasiswa akuntansi lebih baik dibandingkan dengan Dosen Akuntansi.

Begitu sebaliknya pada persepsi Kebutuhan Akuntan Profesional persepsi Dosen Akuntansi lebih baik dibandingkan dengan mahasiswa akuntansi.

Dikarenakan penelitian ini penelitian sederhana hanya diruang lingkup Prodi Akuntansi Fakultas Ekonomi Universitas Lancang Kuning, maka dapat diluaskan pada seluruh Institusi pendidikan untuk wilayah pekanbaru atau Riau pada bidang Akuntansi.

Hasil penelitian diatas dapat dijadikan nilai masukan untuk Dosen Akuntansi dalam meningkatkan Pandangan, Wawasan dan Ilmu Pengetahuan mengenai MEA.

\section{DAFTAR RUJUKAN}

Abdulrofiq, Atep. (2013). Manakar Pengaruh Masyarakat Ekonomi ASEAN terhadap Pembangunan Ekonomi Indonesia. I (1): 1-8.

Andadari, Roos. 2013.Persepsi Mahasiswa Indonesia dalam Pemberlakuan Masyarakat ASEAN. Universitas Kristen Satya Wacana. Salatiga

Andersen, William., Anis Chariri. (2012). Analisis Persepsi Mahasiswa Akuntansi dalam Memilih Profesi sebagai Akuntan (Studi Empiris pada Mahasiswa Akuntansi UNDIP, UNIKA, UNNES, UNISSULA, UDINUS, UNISBANK, STIE TOTAL Win dan Mahasiswa PPA UNDIP). Diponegoro Journal of Accounting. VOL. 1, I (1):1-14. 
Avianti, I. 2015. Peluang dan Tantangan Akuntan di Era MEA. Simposium Nasional Akuntansi (SNA) XVIII, Medan.

Ghozali, Imam. (2012). Aplikasi Analisis Multivariate dengan Program SPSS. Cetakan IV. Semarang: Badan Penerbit Universitas Diponogoro.

Ibrahim, Nabil A.., John P. Angelidis., Donald P. Howard. (2006). Corporate Social Responsibility: A Comparative Analysis of Perceptions of Practicing Accountants and Accounting Students. Journal of Business Ethics. DOI 10.107/S10551-0055572-4:157-167.

Kotler, Phillip. (1993). Manajemen Pemasaran Analisis, Perencanaan Implementasi dan Kontrol. Edisi Bahasa Indonesia. Jilid 2: Prentice Hall.

Ni Nyoman Alit Triani, Erlina, Merlyana (2015) Kesiapan Profesi Akuntan Di Indonesia Dalam Menghadapi Mea. ISSN 2460-0784 Seminar Nasional dan The 2nd Call for Syariah Paper.

Rahayu, Sri, Eko Arief Sudaryono, Doddy Setiawan. (2003). Persepsi Mahasiswa Akuntansi Mengenai Faktor-Faktor yang Mempengaruhi Pemilihan Karir sebagai Akuntan Publik. Jurnal Bisinis dan Ekonomi, VOL. 10.

Suatma, Jasa. (2012). Kesiapan Indonesia dalam Menghadapi ASEAN Economic Community 2015. Jurnal STIE Semarang, VOL 4, I (1): 1-7.

Sulistyawati, Ardiani Ika., Nina Ernawati., Netty Sylviana. (2013). Persepsi Mahasiswa Akuntansi Mengenai Faktor-Faktor yang Mempengaruhi
Pemilihan Karir. Jurnal Dinamika Akuntansi VOL. 5, II : 86-98.

Suttipun, Muttanachai.2014. The Readiness of Thai Accounting Students for the ASEAN Economic Community: An Exploratory Study. JURNAL. Asian Journal of Business and Accounting 7(2).

Suyatmin. (2008). Persepsi Mahasiswa Akuntansi Terhadap Lingkungan Kerja Akuntan Publik. Juurnal Akuntansi dan Keuangan, VOL 7, I (1): 1-13.

Triani, N., Nyoman, A., Erlina, D., dan Merlyana D.Y., (2015). Kesiapan Profesi Akuntan di Indonesia dalam Menghadapi MEA. Syariah Paper Accounting FEB UMS, 612-625.

Winarna, Jaka., Ninuk Retnowati. (2003). Persepsi Akuntan Pendidik, Akuntan Publik dan Mahasiswa Akuntansi terhadap Kode Etik Ikatan Akuntan Indonesia. Simposium Nasional Akuntansi VI IAI-KAPd Oktober

Penelitian ini dibiayai oleh APBF Fakultas Ekonomi Universitas Lancang Kuning, sesuai dengan surat perjanjian pelaksanaan penelitian Nomor 034/Unilak.02/UPPM/B.07/2018 